\title{
A recovery of harbour porpoises (Phocoena phocoena) in the southern North Sea? A case study off Eastern Frisia, Germany
}

Received: 28 June 2005/ Revised: 2 January 2006/ Accepted: 3 January 2006/Published online: 25 February 2006 (c) Springer-Verlag and AWI 2006

\begin{abstract}
Detailed information on year-round distribution, seasonal abundance and inter-annual trends of a given species is essential for any conservation effort. However, for most odontocetes this knowledge is rather limited. Therefore, area-specific management or conservation plans are often difficult to argue for. This is also true for the harbour porpoise (Phocoena phocoena), although it is the most common cetacean species in the North Sea. Knowledge of the current status of local stocks as well as fine scale information on the temporal use of certain areas by the species is incomplete. One area of concern is the southern North Sea where the abundance of harbour porpoises has declined in the twentieth century. Recent studies using stranding data and observations from seabird surveys indicate a comeback of the species along the Dutch and Belgian coast. However, data on other regions of the southern North Sea is sparse. Between 2002 and 2004, we undertook 25 aerial line transect surveys $(11,000 \mathrm{~km}$ on effort; altitude $=250$ and $600 \mathrm{ft}$ ) in a $2,500 \mathrm{~km}^{2}$ coastal area off Eastern Frisia, Germany including a small portion of Dutch coastal waters. The data were $g(0)$ corrected using a double platform approach and analysed with distance sampling software. A total of 426 harbour porpoises were sighted, including eight calves. Densities ranged between $<0.1$ and 1.62 individuals/ $\mathrm{km}^{2}$ with peaks in February and July 2003 as well as February and May 2004. The results of our study show that harbour porpoises are present in the coastal part of the southern North Sea even during their reproductive period. However, they seem to appear in lower numbers
\end{abstract}

Communicated by H.-D. Franke

F. Thomsen · M. Laczny $\cdot$ W. Piper

Biologisch-landschaftsökologische-Arbeitsgemeinschaft (biola),

Gotenstraße 4, 20097 Hamburg, Germany

F. Thomsen $(\bowtie)$

Biozentrum Grindel, Universität Hamburg,

Martin-Luther-King-Platz 3, 20146 Hamburg, Germany

E-mail: drthomsen@web.de and much more irregular than in other areas, for example off Northern Frisia. The results of this study support the recent findings that despite a decline in the mid-twentieth century, harbour porpoises are now at times quite abundant in the southern North Sea. The underlying factors of this 'return' should be investigated using a combination of surveys and satellite telemetry.

Keywords Harbour porpoises - Southern North Sea

\section{Introduction}

Detailed information on year-round distribution, seasonal abundance and inter-annual trends of a given species is essential for any conservation effort. However, for most odontocetes this knowledge is rather limited. Therefore, area-specific conservation plans are often difficult to argue for. This is especially true for the harbour porpoise (Phocoena phocoena), although it is the most abundant cetacean species in the North Sea. In 1994, their number therein was estimated at 270,000 animals (SCANS-survey; Hammond et al. 2002). Areas of highest population densities appear to be in the north-western North Sea and along the German and Danish west coasts (Heide Jørgensen et al. 1993; Bjørge and Øien 1995; Hammond et al. 2002; Reid et al. 2003; Scheidat et al. 2004a, b). In other areas though, harbour porpoises have reportedly declined or seem to have disappeared in the twentieth century, most notably in the eastern Channel and the southern North Sea (Camphuysen 1982; Northridge et al. 1995; Reijnders et al. 1996; Addink and Smeek 1999). It has been suggested that human activities such as overfishing, incidental catches in fishing gear, noise pollution and habitat degradation are likely to have contributed to this decline (ASCOBANS 2005). In 2004, ASCOBANS initiated a 'recovery plan for harbour porpoises in the North Sea' with the objectives to identify risks for the species and 'to suggest management measures which will achieve and maintain a favourable conservation 
status of harbour porpoises in their entire range' (ASCOBANS 2005). Important steps of such a plan would be to first collect more information on possible areas of concern, and then to establish mitigation measures to support the recovery of stocks in these 'problem areas'. But even the first step might be quite difficult to achieve. For example, recent studies using mainly stranding data and observations from seabird surveys, indicate a comeback of harbour porpoises in the southern North Sea, most notably along the Dutch and Belgian coast (Camphuysen 1994, 2004; Witte et al. 1998; Haelters et al. 2004). However, these studies provided no estimates on absolute densities of porpoises. Hammond et al. (2002) reported low densities for the coastal part of Belgium, Netherlands and Eastern Frisia in 1994. Scheidat et al. (2004a) undertook four largescale aerial line transect surveys off Eastern-Frisia in May-August 2002/2003 and found low densities too, but both survey areas were large and the effort therein comparably low. Therefore, both studies only represent a snapshot at best. No study has looked at the absolute density of harbour porpoises within the southern North Sea on a year-round basis with at least monthly surveyintervals. Therefore, our understanding of the status of harbour porpoises in the southern North Sea is still rather limited.

Here we report findings from a systematic case study on the abundance of harbour porpoises in a $2,500 \mathrm{~km}^{2}$ area off Eastern Frisia, Germany including a small portion of Dutch coastal waters. Data were collected using line transect aerial surveys on a monthly basis between December 2002 and July 2004. In this paper, we will present data on relative and absolute densities of harbour porpoises. Based on our results, the status of harbour porpoises in this part of the southern North Sea will be discussed.

\section{Methods}

\section{Data collection}

The study took place between December 2002 and July 2004. The study area was located off Eastern Frisia partly extending into Dutch waters $\left(53^{\circ} 30.000^{\prime}-\right.$ $\left.53^{\circ} 57.295^{\prime} \mathrm{N} ; 006^{\circ} 00.100^{\prime}-007^{\circ} 10.105^{\prime} \mathrm{E}\right)$. The area was situated near shore with water depth varying from $<10$ to $30 \mathrm{~m}$. Data were collected using line transect methodology following the distance sampling approach after Buckland et al. (2001) (see also Thomsen et al. 2004 for a detailed methodology in German), which was also applied in the first SCANS survey. A total of 16 transect lines were placed perpendicular to the coastline with line length between 26 and $33 \mathrm{~km}$. From December 2002 until mid July 2003 the survey area comprised 1,400 $\mathrm{km}^{2}$ with spacing between the lines of $3 \mathrm{~km}$ and a total transect length of $482 \mathrm{~km}$. From the end of July 2003 until July 2004 app. $2,500 \mathrm{~km}^{2}$ were surveyed with a line spacing of $5 \mathrm{~km}$ and total transect length of $500 \mathrm{~km}$

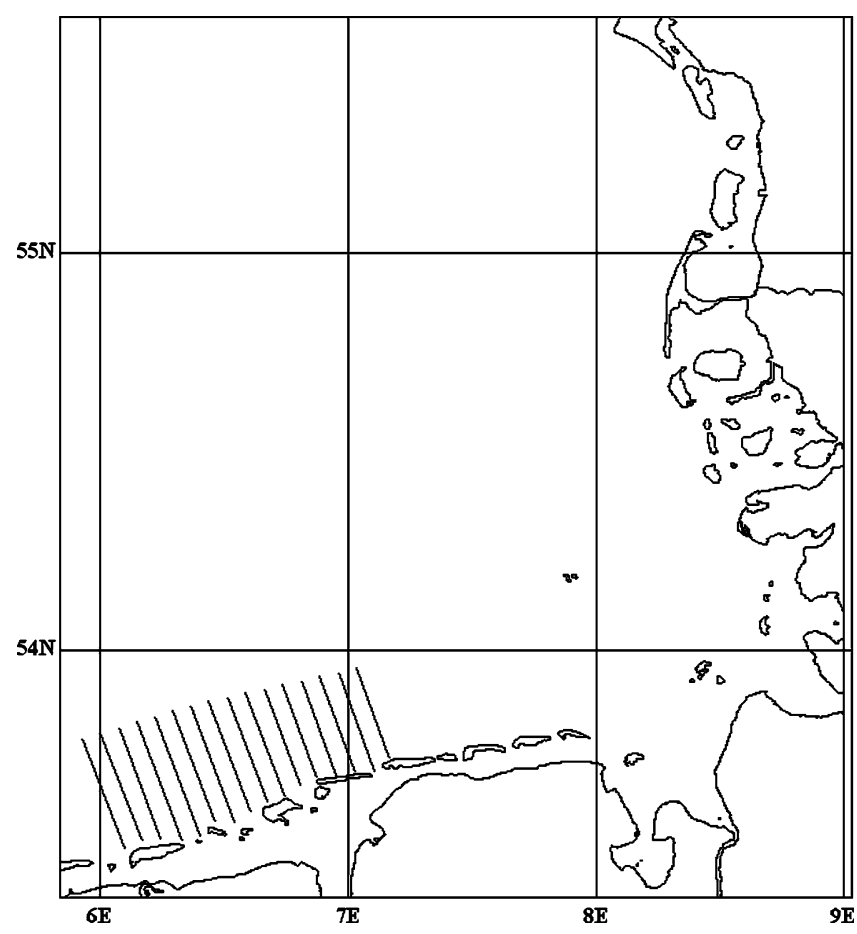

Fig. 1 The study area and the transect layout in 2003/2004

(Fig. 1). The survey plane was a high-winged, twin-engine BN-Islander, equipped with bubble windows on the rear seats. Survey flights were generally restricted to calm weather and good visibility (seastate $<3 \mathrm{bft}$, visibility $>5 \mathrm{~km}$ ). Data were collected during specialized marine mammal trips at an altitude of $600 \mathrm{ft}(183 \mathrm{~m})$ as well as during combined porpoise/seabird surveys at an altitude of $250 \mathrm{ft}(76 \mathrm{~m})$. Initially, five porpoise-only flights were undertaken between December 2002 and June 2003. From July 2003 until July 2004, both methods were used with at least one survey per month (see Table 2).

The flights were conducted with three observers: two principal observers were placed at the rear bubble windows (search angle $=0^{\circ}$ to $<60^{\circ}$ ). One control observer was placed at a flat window behind the pilot (search angle $=20^{\circ}$ to $<60^{\circ}$ ). The principal observers switched places during a break at half time, the control observer switched places on each transect, depending on sighting conditions. Observers were acoustically isolated from each other through ear plugs and headphones. At the onset of the survey, the observers searched continuously for porpoises. At each sighting, the exact time was noted (UTC, synchronised with onboard GPS, model LX-20-2000 Flight Recorder, Filser Electronics) and recorded aurally on dictaphone. The sighting angle was measured with an clinometer (Suunto PM 5/360 PC) and also noted. Additionally, data on group size, travel direction and the behaviour of the animals were recorded. The flight-track was logged and stored continuously in $3 \mathrm{~s}$ intervals on a Notebook, which was connected to the board GPS and displayed using the Fugawi 3.0 software-program. 
Thus, it was possible to correct deviations from the track line immediately.

\section{Data analysis}

\section{Calculation of sighting rates}

Based on the field notes of the observers, the transects were assigned as valid one sided, valid both sided or invalid. Only valid transects were analysed. Since control- and principal observers had different search angles (see above), only the sightings of the latter ones were used in the quantitative analysis. Porpoise-only flights (altitude $=183 \mathrm{~m}$ ) and combined porpoise/seabird ones $(76 \mathrm{~m})$ were analysed independently. We first calculated the sighting rate, which was defined as the number of porpoises per $\mathrm{km}$ for each transect of each flight. We then calculated the mean sighting rate for each flight. Sighting rates across flights were compared with a Kruskal-Wallis $H$-test. If means differed, we performed a multiple all-pairwise comparison following Dunn's method (Zar 1984).

\section{Calculation of absolute densities}

Absolute densities were calculated with the DISTANCE 4.1 software-program (Thomas et al. 2003). Distances $x$ to the observation were calculated as $x=v \times \tan \left(90^{\circ}-\right.$ $\varnothing)$ with $v$ being the altitude in $\mathrm{m}$ and $\varnothing$ the angle of declination measured with the clinometer (Buckland et al. 2001). We then calculated the effective strip half-width (esw) cumulatively for all porpoises only and combined porpoise/seabird flights independently using only flights with $>10$ sightings. For this calculation, we used a hazard-rate key function with a simple polynominal series expansion. The corresponding esw was $169 \mathrm{~m}$ for the porpoise-only flights and $106 \mathrm{~m}$ for the combined porpoise/seabird surveys (Fig. 2). Densities were calculated for each flight as $D=n \times G / 2 \mu \times L$ with $n$ being the number of sightings, $G$ the average group

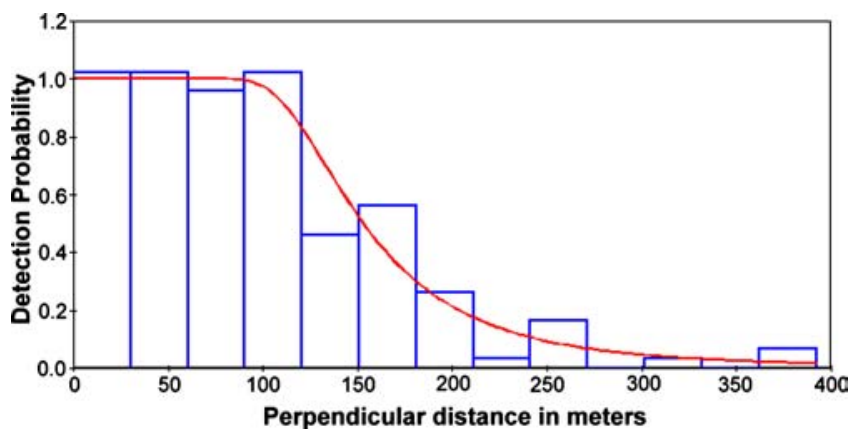

Fig. 2 Detection probability function for harbour porpoises during seven of 12 porpoise-only aerial surveys (altitude $=183 \mathrm{~m}$; model $=$ hazard rate key function with simple polynominal series expansion; $n=170$ sightings) size, $L$ total transect-length, and $\mu$ the effective strip halfwidth (Buckland et al. 2001).

\section{$g(0)$ correction}

One important assumption in line-transect surveys is that $\mathrm{g}(0)$, the probability to detect an object on the track line, is 1.0. In cetacean surveys this is not the case, because observers sometimes miss animals present (= perception bias) and diving individuals are unavailable for detection (=detection bias). The corrected density therefore is $D=D^{x} \times 1 / g(0)$ (after Borchers 2003). We calculated a correction for $g(0)$ by using a mark-recapture method combined with published diving data for harbour porpoises after a method used by Grünkorn et al. (2003, 2005). We estimated the perception bias as $p(\mathrm{~m})=N 12 / N 1$, where $p(\mathrm{~m})$ is the probability of detection by the principal observer, N12 the number of duplicates between main- and control observer (search angle $=20-45^{\circ}$ ), and $N 1$ the number of individuals seen by the control-observer. For the availability bias, we first multiplied the number of sightings on each flight with the individual surface time, i.e. the percentage of time porpoises are present in the $0-1 \mathrm{~m}$ water column (Teilmann 2000) to get an estimate on the average surface time. The average surface time for the porpoise-only flights was 0.43 with the sighting probability being 0.55 (Table 1 ). This resulted in a $g(0)$ of 0.43 $\times 0.55=0.24$. For the combined porpoise/seabird flights, surface time was 0.51 and the sighting probability was 0.71 resulting in a $g(0)$ of 0.36 .

\section{Results}

Table 2 shows the effort and the harbour porpoise sightings obtained during the study period (December 2002-July 2004). We undertook 25 surveys (12 porpoiseonly flights; 13 combined porpoise/seabird flights) with a total effort of about $11,000 \mathrm{~km}$. With only a few exceptions, we flew at monthly intervals, in many months two flights were undertaken. We recorded 371 sightings with 426 individuals (mean group size $=1.15$ ). Porpoises were most often encountered alone (88.5\%). Pairs and groups of three or four animals were rare $(9.4 \%, 1.3 \%$ and $0.8 \%$, respectively). A total of eight calves were observed (June-August $2003=4$, July $2004=4)$. Calving rates were $10 \%$ in June 2003, 3.6\% in July 2003 and $10.8 \%$ in July 2004 .

Porpoises occurred irregular in the study area (Table 2, Fig. 3). Between December 2002 and July 2003 peaks in relative abundance were present in February and July. Between August and December 2003 porpoises were only sporadically seen. Sightings increased again in February 2004 and stayed on a comparably high level until the beginning of May 2004. During that period 10 of the 25 surveys were carried out $(40 \%$ of survey effort in $\mathrm{km}$ ) and about $65 \%$ of all porpoises were seen. 
Table 1 Estimation of $g(0)$ for the porpoise-only flights

\begin{tabular}{|c|c|c|c|c|c|}
\hline Date & $\begin{array}{l}\text { Number } \\
\text { of sightings }^{\text {a }}\end{array}$ & $\begin{array}{l}\text { Individual } \\
\text { surface time }\end{array}$ & $\begin{array}{l}\text { Total } \\
\text { surface time }\end{array}$ & $N 1$ & $N 1 \& 2$ \\
\hline $02 / 17 / 03$ & 24 & $0.44^{\mathrm{b}}$ & 10.56 & 5 & 2 \\
\hline $06 / 07 / 03$ & 16 & 0.39 & 6.24 & 7 & 5 \\
\hline $07 / 10 / 03$ & 26 & 0.41 & 10.66 & 12 & 8 \\
\hline $02 / 16 / 04$ & 27 & $0.44^{\mathrm{b}}$ & 11.88 & 1 & 1 \\
\hline $05 / 03 / 04$ & 50 & 0.45 & 22.50 & 7 & 4 \\
\hline \multicolumn{4}{|c|}{ Availability bias/average surface time $=0.43$} & \multicolumn{2}{|c|}{$\begin{array}{l}\text { Perception bias/sighting } \\
\text { probability }=0.55\end{array}$} \\
\hline
\end{tabular}

Altitude $183 \mathrm{~m} ; N 1 \& 2$ duplicate sightings of control and principal observer between 20 and $45^{\circ}, N 1$ sightings of control observer only ${ }^{a}$ Sightings of principal observer in valid transect sections

${ }^{\mathrm{b}}$ Average after Teilmann (2000)

In June 2004, porpoises were almost absent and in the following month sighting rates increased again. For the porpoise-only flights there were significant differences in sighting rates between surveys $(H$ test, $d f=11$, $H=75.79, P<0.001)$. The sighting rates in February 2003, 2004 and in May 2004 were each significantly higher than during December 2002, April, August and October 2003 as well as June 2004 (Dunn's method $P<0.05)$. The sighting rate in July 2003 was significantly higher than during December 2002, April 2003 and June 2004 (Dunn's method $P<0.05$ ). For the combined porpoise/seabird flights, sighting rates also differed between months ( $H$ test, $d f=12, H=55.27, P<0.001$ ).

Table 2 Harbour porpoise sightings in 2002-2004

\begin{tabular}{|c|c|c|c|c|c|}
\hline Date & $\begin{array}{l}\text { Altitude } \\
(\mathrm{m})\end{array}$ & $\mathrm{km}$ on effort & $S$ & $I$ & Calves \\
\hline $12 / 13 / 02$ & 183 & 425 & 1 & 1 & \\
\hline $02 / 17 / 03$ & 183 & 431 & 24 & 33 & \\
\hline $04 / 24 / 03$ & 183 & 363 & 1 & 1 & \\
\hline $05 / 07 / 03$ & 183 & 411 & 11 & 14 & \\
\hline $06 / 07 / 03$ & 183 & 446 & 16 & 20 & 2 \\
\hline $07 / 10 / 03$ & 183 & 381 & 26 & 28 & 1 \\
\hline $07 / 21 / 03$ & 76 & 440 & 5 & 7 & \\
\hline $08 / 04 / 03$ & 183 & 366 & 2 & 3 & 1 \\
\hline $08 / 10 / 03$ & 76 & 452 & 7 & 7 & \\
\hline $09 / 20 / 03$ & 76 & 486 & 5 & 5 & \\
\hline $10 / 02 / 03$ & 76 & 453 & 8 & 9 & \\
\hline $10 / 16 / 03$ & 183 & 413 & 5 & 5 & \\
\hline $11 / 28 / 03$ & 76 & 488 & 5 & 5 & \\
\hline $12 / 09 / 03$ & 76 & 502 & 7 & 9 & \\
\hline $02 / 16 / 04$ & 183 & 502 & 27 & 37 & \\
\hline $02 / 16 / 04$ & 76 & 502 & 26 & 28 & \\
\hline $03 / 03 / 04$ & 76 & 445 & 39 & 42 & \\
\hline $03 / 18 / 04$ & 76 & 503 & 22 & 23 & \\
\hline $04 / 14 / 04$ & 76 & 378 & 30 & 34 & \\
\hline $05 / 03 / 04$ & 183 & 454 & 50 & 53 & \\
\hline $05 / 28 / 04$ & 76 & 502 & 19 & 19 & \\
\hline $06 / 02 / 04$ & 76 & 502 & 4 & 4 & \\
\hline $06 / 03 / 04$ & 183 & 478 & 2 & 2 & \\
\hline $07 / 21 / 04$ & 76 & 487 & 13 & 16 & 2 \\
\hline $07 / 22 / 04$ & 183 & 413 & 16 & 21 & 2 \\
\hline Sum & & 11,223 & 371 & 426 & 8 \\
\hline
\end{tabular}

$\mathrm{km}$ on effort valid effort on both sides, $S$ number of sightings, $I$ number of individuals
Here, the sighting rates in February, March and April 2004 were each significantly higher than in July, September and November 2003 and in June 2004 (Dunn's method $P<0.05$ ).

Absolute estimates of abundance could be calculated for 13 of the 25 surveys (Table 3). Estimated densities varied between 0.38 porpoises per $\mathrm{km}^{2}$ in July 2004 and 1.62 per $\mathrm{km}^{2}$ in May 2004. Depending on absolute density values and size of the area, between 560 and 4,200 porpoises were present in the study area. It has to be noted, however, that for 12 flights no absolute densities could be calculated, indicating an abundance of less than 560 animals. The above mentioned seasonal variation was also found in the absolute density values, most evidently for the summer months. From the nine surveys undertaken during June-August in both years, absolute densities could be calculated for four surveys with corresponding values between 0.38 and 1.00 individuals $/ \mathrm{km}^{2}$. The remaining five surveys did not produce enough sightings for a quantitative analysis, and hence the densities of porpoises should be viewed as low ones. In contrast, absolute densities could be calculated for

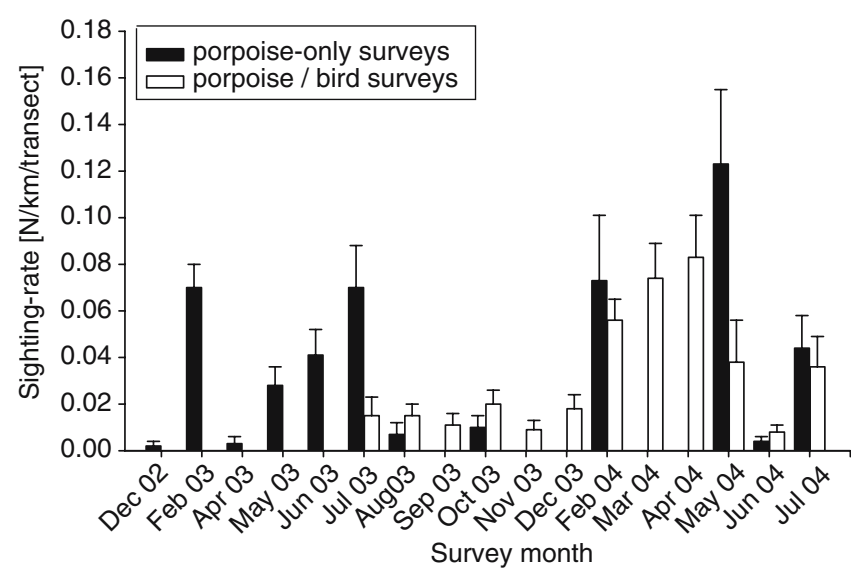

Fig. 3 Relative frequency of occurrence $(n / \mathrm{km}$ transect) of harbour porpoises during the study period (mean $\pm \mathrm{SE}$ ) 
Table 3 Densities of harbour porpoises in the study area 2003/2004

\begin{tabular}{|c|c|c|c|c|c|c|c|}
\hline Date & $\begin{array}{l}\text { Altitude } \\
\text { (m) }\end{array}$ & $\mathrm{g}(0)$ & $\begin{array}{l}\text { esw } \\
(\mathrm{m})\end{array}$ & $\begin{array}{l}\text { Density } \\
\text { (Ind./km²) }\end{array}$ & $\begin{array}{l}\text { Density } \\
\text { CV }\end{array}$ & $\begin{array}{l}\text { Area size } \\
\left(\mathrm{km}^{2}\right)\end{array}$ & $N \pm S E$ \\
\hline $02 / 17 / 03$ & 183 & 0.24 & 169 & 0.85 & 0.19 & 1.438 & 1,232 (239) \\
\hline $06 / 07 / 03$ & 183 & 0.24 & 169 & 0.52 & 0.28 & 1.438 & 762 (213) \\
\hline $07 / 10 / 03$ & 183 & 0.24 & 169 & 1.00 & 0.28 & 1.438 & 1,449 (409) \\
\hline $02 / 16 / 04$ & 183 & 0.24 & 169 & 0.79 & 0.18 & 2.588 & $2,058(387)$ \\
\hline $02 / 16 / 04$ & 76 & 0.36 & 106 & 0.75 & 0.17 & 2.588 & 1,937 (332) \\
\hline $04 / 14 / 04$ & 76 & 0.36 & 106 & 1.15 & 0.20 & 2.588 & $3,000(625)$ \\
\hline $05 / 03 / 04$ & 183 & 0.24 & 169 & 1.62 & 0.27 & 2.588 & $4,211(1,158)$ \\
\hline $05 / 28 / 04$ & 76 & 0.36 & 106 & 0.48 & 0.28 & 2.588 & $1,265(357)$ \\
\hline 07/21/04 & 76 & 0.36 & 106 & 0.38 & 0.36 & 2.588 & 999 (362) \\
\hline $07 / 22 / 04$ & 183 & 0.24 & 169 & 0.57 & 0.27 & 2.588 & $1,483(409)$ \\
\hline
\end{tabular}

$g(0)$ Probability of detection at distance 0 from the transect-line, esw effective strip half-width, $C V$ coefficient of variation, $N$ estimated number of animals present in the study area, $\pm S E$ standard error

each survey between February and May 2004 and ranged between 0.48 and 1.62 individuals $/ \mathrm{km}^{2}$ (Table 3).

\section{Discussion}

The results of our study show that harbour porpoises are present year-round in this part of the southern North Sea, sometimes in relatively high densities of more than 1.0 individuals $/ \mathrm{km}^{2}$. It should be noted, however, that our calculations of $g(0)$ and hence the resulting absolute densities are rather rough estimates, since the diving patterns of the porpoises in the study area are not known. Yet, the results of an investigation in Canadian coastal waters confirm that porpoises spend about $40 \%$ of their time in the water column of $0-1 \mathrm{~m}$, making the assumption realistic that a general factor of 2-3 might be applicable for the availability bias (Westgate et al. 1995). It is true that visibility has varied across all flights and even within one survey, depending on algae-blooms, reflections from clouds and turbidity. But it appears likely that 'bad' and 'good' visibility have levelled out each other over the course of the study. Hence, a general visibility of up to $1 \mathrm{~m}$ into the water column might be quite feasible to work with. Our estimates of $g(0)$ correspond well with assumptions from other investigations that varied between 0.25 and 0.3 , and might therefore be viewed as realistic (Hiby and Lowell 1998; Hammond et al. 2002; Grünkorn et al. 2003). Recently, Palka (2005) and Scheidat et al. (2005) tested a new method using one plane that is circling back the track line in case of an encounter ('circle-back-method'; Hiby 1999). They estimated a $g(0)$ of $0.40-0.56$ in good conditions and a $g(0)$ of 0.164 under moderate ones. However, sample sizes were small, resulting in very large confidence intervals. The advantage of this method is that perception- and availability-bias can be estimated simultaneously. However, further tests with much larger sample-sizes are needed to confirm the feasibility of the circle-back method (Scheidat et al. 2005). The difference between the porpoise-only and combined porpoise/seabird $g(0)$ in our study are most likely due to perception of porpoises at different altitudes. Since individuals appear bigger at $76 \mathrm{~m}$ compared to $183 \mathrm{~m}$, the chance of resighting was probably higher during the combined porpoise/seabird surveys than during the porpoise-only ones.

We found that despite the year-round presence, the occurrence of harbour porpoises in the study area was rather irregular, both within and between seasons. Especially during summer (June-August), mid to high densities were followed by rather low occurrence of porpoises. Scheidat et al. (2004a) estimated a relatively low density of 0.18 per $\mathrm{km}^{2}$ off the coast of Eastern Frisia for May-August 2003. However, since only one survey was carried out during that time and in this particular area, fine scale shifts in distribution, for example movements from the northern or the central German Bight towards the coast of Eastern Frisia, resulting in temporarily mid to high densities there, might have been missed. The same is true for Hammond et al. (2002), who based their estimate of 0.09 individuals $/ \mathrm{km}^{2}$ for SCANS-block $\mathrm{H}$ (coast of Belgium, Netherlands, and Eastern Frisia) on a survey effort of only $212 \mathrm{~km}$ in Beaufort <3, between June and July 1994. Camphuysen (2004) reported only a few sightings off the Dutch coast between June and July of the years 2001-2004, but he noted a mid-summer peak in August of the years 2001-2004 with increased sighting-rates of mother and calf pairs. In summary, our results show that harbour porpoises do occur in this part of the southern North Sea in summer, sometimes with almost high densities, but their appearance is much more irregular and calving rates are considerably lower than at peak-times in other areas, for example off Denmark and Northern Frisia (Adelung et al. 1997; Hammond et al. 2002; Grünkorn et al. 2003; Scheidat et al. 2004a, b).

The finding that in our study area harbour porpoises occurred more often and on a more regular basis between February and May also corresponds with the results of Camphuysen (2004) and Haelters et al. (2004), 
who both found a comparably high number of harbour porpoises in February and March. However, in contrast to their results, the densities in our study remained on a relatively high level until May (Fig. 3). It is likely that the increased densities in early spring might be caused by a higher availability of primary prey species. Haelters et al. (2004) suspect that the increase of harbour porpoises in the southern North Sea might be related to the recovery of the North-Sea stock of herring (Clupea harengus). Currently, studies are underway to compare the distribution of harbour porpoises within the North Sea with the phenology of valuable prey such as herring, sandeels (Ammodytidae) and other fish species.

The results of this study support the recent findings that despite a decline in the mid-twentieth century, harbour porpoises are now at times quite abundant in the southern North Sea (Camphuysen 1994, 2004; Witte et al. 1998; Haelters et al. 2004). It is therefore questionable, if the area should be considered as a 'region of concern' to be included in a recovery plan. Probably, the situation will not change considerably within the next years, since both in Germany and the Netherlands, bycatch rates are at present relatively low (Reijnders et al. 1996; ASCOBANS 2005). However, it is unlikely, that the recent come-back of harbour porpoises in the southern North Sea is explained by a recovery of a 'local population'. First, it is under debate if a separate sub-population exists in the southern North Sea (Andersen 2003). Second, the annual increase of $40 \%$ in sighting-rates observed by Camphuysen (2004) exceeds by far the maximum potential rate of increase of $10 \%$ for the species (Stenson 2003; Camphuysen 2004). Therefore, changes in occurrence of the species in parts of the North Sea might not result from a recovery but rather from a recruitment of porpoises from other areas, which might in turn be caused by environmental factors such as the reduced availability of prey (Camphuysen 2004). The current status of harbour porpoises in the North Sea could probably only be investigated thoroughly using a combination of surveys, genetic studies and satellite telemetry.

Acknowledgements We would first like to thank 'ENOVA Energieanlagen GmbH' for the opportunity to present the data. We thank all the observers for their great engagement for the project. Finally, we would like to thank the 'Ostfriesische Lufttransport GmbH' (Emden) for the close cooperation.

\section{References}

Adelung D, Heidemann G, Frese K, Duinker J, Haase E, Schulz G (1997) Untersuchung an Kleinwalen als Grundlage eines Monitorings. BMBF-Projekt 03F0139A, Schlussbericht

Addink MJ, Smeek C (1999) The harbour porpoise Phocoena phocoena in Dutch coastal waters: analysis of stranding records for the period 1920-1994. Lutra 41:55-80

Andersen LW (2003) Harbour porpoises (Phocoena phocoena) in the North Atlantic: distribution and genetic population structure. In: Haug T, Desportes G, Vikingson GA, Witting L (eds)
Harbour porpoises in the North Atlantic. NAMMCO Scientific Publications, Tromso, pp 11-31

ASCOBANS (2005) Recovery plan for harbour porpoise (Phocoena phocoena) in the North Sea. Document AC 12/Doc. 17. ASCOBANS, Bonn (www.ascobans.org)

Bjørge A, Øien N (1995) Distribution and abundance of harbour porpoise Phocoena phocoena in Norwegian waters. In: Bjørge A, Donovan GP (eds) Biology of the Phocoenids. Rep Int Whal Commn Cambridge special issue 16, pp 89-98

Borchers DL (2003) Estimation with incomplete detection at distance zero ' $g(0)<1$ '. In: International workshops. Advanced techniques and recent developments in distance sampling. Centre for Research into Ecological and Environmental Modelling, St Andrews, pp 102-129

Buckland ST, Anderson DR, Burnham KP, Laake JL, Borchers DL, Thomas L (2001) Introduction to distance sampling. Oxford University Press, Oxford

Camphuysen CJ (1982) Zezoogdieren langs de Nederlandse kust. Medelingen Club van Zeetrekwaarnemers 5:6-8

Camphuysen CJ (1994) The harbour porpoise Phocoena phocoena in the southern North Sea: a come-back in Dutch coastal waters? Lutra 37:54-61

Camphuysen CJ (2004) The return of the harbour porpoise (Phocoena phocoena) in Dutch coastal waters. Lutra 47:113122

Grünkorn TA, Diederichs A, Gruber S, Nehls G (2003) Seasonal distribution patterns and density of harbour porpoises (Phocoena phocoena) in the North Sea Offshore of Sylt, Germany. In: Abstracts of the 17th annual conference of the ECS, Las Palmas, 9-13 March 2003, European Cetacean Society, Las Palmas, p 254

Grünkorn TA Diederichs A, Nehls G (2005) Aerial surveys in the German Bight - estimating $g(0)$ for harbour porpoises (Phocoena phocoena) by employing independent double counts. In: Thomsen F, Ugarte F, Evans PGH (eds) Estimation of $g(0)$ in line-transect surveys of cetaceans. European Cetacean Society Newsletter No. 44, special issue, pp 25-34

Haelters J, Kiska JJ, Jauniaux T, Tavernier J (2004) The harbour porpoise in the southern North Sea a come-back in Northern French and Belgian waters? In: Abstracts of the 18th annual conference of the ECS, Kolmarden, 28-31 March 2004, European Cetacean Society, Kolmarden, p 67

Hammond PS, Berggren P, Benke H, Borchers DL, Collet A, Heide-Jørgensen MP, Heimlich S, Hiby AR, Leopold MF, Øien N (2002) Abundance of the harbour porpoise and other cetaceans in the North Sea and adjacent waters. J Appl Ecol 41:1129-1139

Heide-Jørgensen MP, Teilmann J, Benke H, Wulf J (1993) Abundance and distribution of harbour porpoises Phocoena phocoena in selected areas of the western Baltic and the North Sea. Helgoländer Meeresunters 47:335-346

Hiby AR (1999) The objective identification of duplicate sightings in aerial surveys for porpoises. In: Garner GW, Amstrup SC, Laake JL, Manly LL, McDonald LL, Robertson DG (eds) Marine mammal survey and assessment methods. A. A. Balkema, Rotterdam, pp 179-190

Hiby AR, Lovell P (1998) Using aircraft in tandem formation to estimate abundance of harbour porpoises. Biometrics 54: $1280-1289$

Northridge SP, Tasker ML, Webb A, Williams JM (1995) Distribution and relative abundance of harbour porpoises (Phocoena phocoena Gray), whitebeaked dolphins (Lagenorhynchus albirostris) and minke whales (Balaenoptera acutorostrata Lacepede) around the British Isles ICES. J Mar Sci 52:55-66

Palka D (2005) Aerial surveys in the northeast Atlantic: estimation of $g(0)$. In: Thomsen F, Ugarte F, Evans PGH (eds) Estimation of $g(0)$ in line-transect surveys of cetaceans. European Cetacean Society Newsletter No. 44, special issue, pp 12-17

Reid JB, Evans PGH, Northridge SP (2003) Atlas of Cetacean distribution in north-west European waters. Joint nature Conservation Committee, Peterborough, UK 
Reijnders PJH, Leopold MF, Camphuysen CJ, Heessen HJL, Kastelein RA (1996) The status of harbour porpoises in Dutch waters and state of related research in the Netherlands an overview-SC/47SM41. Rep Int Whal Commn 46: 607-611

Scheidat M, Gilles A, Siebert U (2004a) Erfassung der Dichte und Verteilungsmuster von Schweinswalen (Phocoena phocoena) in der deutschen Nord- und Ostsee-Teilprojekt 3-In: Endbericht Marine Warmblüter in Nord- und OstseeGrundlagen zur Bewertung von Windkraftanlagen im Offshore-Bereich Bundesministerium für Umwelt, Naturschutz Reaktorsicherheit (FKZ 0327520)

Scheidat M, Kock KH, Siebert U (2004b) Summer distribution of harbour porpoise (Phocoena phocoena) in the German North Sea and Baltic Sea. J Cetacean Res Manage 6:251-257

Scheidat M, Gilles A, Siebert U (2005) Applying the circle-back method to estimate $g(0)$ experiences and results from aerial surveys in German waters. In: Thomsen F, Ugarte F, Evans PGH (eds) Estimation of $g(0)$ in line-transect surveys of cetaceans. European Cetacean Society Newsletter No. 44, special issue, pp 18-24

Stenson GB (2003) Harbour porpoise (Phocoena phocoena) in the North Atlantic: abundance, removals, and sustainability of removals. In: Haug T, Desportes G, Vikingson GA, Witting L (eds) Harbour porpoises in the North Atlantic, vol 5. NAMMCO Scientific Publications Tromso, pp 271-303

Teilmann J (2000) The behaviour and sensory abilities of harbour porpoises (Phocoena phocoena) in relation to bycatch in Danish gillnet fishery. $\mathrm{PhD}$ Thesis, University of southern Denmark

Thomas L, Laake JL, Strindberg S, Marques FFC, Buckland ST, Borchers DL, Anderson DR, Burnham KP, Hedley SL, Pollard JH (2003) Distance 41 Release " $x$ "1 Research Unit for Wildlife Population Assessment, University of St Andrews, UK. http:// www.ruwpast-andacuk/distance/

Thomsen F, Laczny M, Piper W (2004) Methodik zur Erfassung von Schweinswalen (Phocoena phocoena) und anderen marinen Säugern mittels Flugtransekt-Zählungen. Seevögel 25:3-12

Westgate AJ, Read AJ, Berggren P, Koopman HN, Gaskin DE (1995) Diving behaviour of harbour porpoises, Phocoena phocoena. Can J Fish Aquat Sci 52:1064-1073

Witte RH, Baptist HJM, Bot PVM (1998) Increase of harbour porpoise (Phocoena phocoena) in the Dutch sector of the North Sea. Lutra 40:33-40

Zar JH (1984) Biostatistical analysis, 2 edn. Prentice Hall, Englewood Cliffs 